\title{
First report of Exomalopsis fulvofasciata (Hymenoptera: Anthophoridae) as host of two Timulla species (Hymenoptera: Mutillidae)
}

\author{
Rodrigo Aranda ${ }^{1,2,3}$ \& Gustavo Graciolli ${ }^{1}$ \\ ${ }^{1}$ Centro de Ciências Biológicas e da Saúde, Universidade Federal de Mato Grosso do Sul - UFMS, \\ Cidade Universitária s/n., CEP 79070-900, Campo Grande, MS, Brasil \\ ${ }^{2}$ Programa de Pós-graduação em Ecologia e Conservação, \\ Universidade Federal de Mato Grosso do Sul-UFMS, CEP 79070-900, Campo Grande, MS, Brasil \\ ${ }^{3}$ Corresponding author: Rodrigo Aranda, e-mail: rodrigoaranda.biologo@gmail.com
}

ARANDA, R. \& GRACIOLLI, G. First report of Exomalopsis fulvofasciata (Hymenoptera: Anthophoridae) as host of two Timulla species (Hymenoptera: Mutillidae). Biota Neotrop. (13)4: http://www.biotaneotropica. org.br/v13n4/en/abstract?short-communication+bn02113042013

Abstract: Two species of Timulla Ashmead that parasitize nests of Exomalopsis fulvofasciata (Hymenoptera: Apidae) in riparian vegetation in the Miranda Pantanal, Mato Grosso do Sul, Brazil were recorded. Also, the behavior of Timulla species, and first report of T. intermissa in the Brazilian Pantanal was reported.

Keywords: parasitoidism, Pantanal, host report, velvet ant, Mutillini.

ARANDA, R. \& GRACIOLLI, G. Primeiro registro de Exomalopsis fulvofasciata (Hymenoptera: Anthophoridae) como hospedeiro de duas espécies de Timulla (Hymenoptera: Mutillidae). Biota Neotrop. (13)4: http://www.biotaneotropica.org.br/v13n4/pt/abstract?short-communication+bn02113042013

Resumo: Registramos duas espécies de Timulla Ashmead parasitando ninhos de Exomalopsis fulvofasciata (Hymenoptera: Apidae) em mata ciliar na região do Pantanal de Miranda, Mato Grosso do Sul, Brasil. Foram observados comportamentos das espécies de Timulla e primeiro registro de T. intermissa para o Pantanal Brasileiro. Palavras-chave: parasitoidismo, Pantanal, registro de hospedeiro, piolho-de-onça, Mutillini. 


\section{Introduction}

Mutillidae are wasps that parasitize mature larvae or pre-pupae of other insects, especially other aculeate Hymenoptera (Brothers et al. 2000). Among the Hymenoptera, their known hosts are Vespidae (Polistinae, Eumeninae), seveval Halictinae and Bombinae (Apidae) (Brothers et al. 2000), Sphecidae and Crabronidae (Quintero \& Cambra 1996, Cambra \& Quintero 1993). About 2-3\% of Mutillidae hosts are known in the world (Brothers 2006). In the Neotropical region, there were an increasing number of records in recent years (e.g. Mickel 1969, Yanega 1994, Cunha 2004, Lima et al. 2008, Bergamaschi et al. 2010, 2011, 2012).

The mutillid Timulla Ashmead includes species from Africa, Asia, Australia and islands of Pacific Ocean (Mickel 1938). One hundred sixty-one Neotropical species were described and little is known about their biology and hosts (Cambra \& Quintero 1993). Most Timulla species have restricted geographic distribution (Mickel 1938) and show high level of host specificity (Wilson 2010). Twentyseven Timulla species were described in Brazil (Mickel 1938), with 12 species recorded in Mato Grosso do Sul state. There is little information on Neotropical Timulla hosts, having records only for T. centroamericana (Dalla Torre, 1897) (Quintero \& Cambra 1996), and T. pictoria Mickel, 1938 (Rocha-Filho et al. 2008). The Timulla fauna is scarcely known in Neotropical region, particularly in the Pantanal, the biggest wetland in the world where only 7 species were recorded (Cresson 1902, Mickel 1938, Aranda \& Catian 2008). In this paper we reported the activity of two species of Timulla parasitizing nests of Exomalopsis fulvofasciata (Smith, 1879) and a new record for T. intermissa (Gerstaecker, 1958) in the Brazilian Pantanal.

\section{Material and Methods}

We collected samples in the riparian forest of Miranda River (19 4'29.85 'S, 57 1'9.02” W). The Pantanal is a vast floodplain, of approximately $140,000 \mathrm{~km}^{2}$, which floods in pulses, characterized by dry periods and low water levels. Flooding is considered one the most selective forces acting on the biota (Junk et al. 1989).

The species of Mutillidae and bee hosts were manually collected, with the use of forceps and entomological hand net, from 14:00 to 17:50h on February 23 and 24, in the rainy season of 2011. Bees' nests were located in an area with sparse vegetation and exposed soil. We counted the number of complete nests and those under construction in five plots of $1 \mathrm{~m}^{2}$. Specimens of Timulla (Mutillidae) were identified with the use of specific keys (Mickel 1938) and comparison with type material from the National Museum of the Universidade Federal do Rio de Janeiro. Specimens of E. fulvofasciata were identified by comparison of deposited material from the Zoological Reference Collection of the Universidade Federal de Mato Grosso do Sul (CEUFMS1936-1940), in Campo Grande identified by Dr. Samuel Viera Boff. The specimens were deposited in the Zoological Reference Collection of Universidade Federal de Mato Grosso do Sul (CEUFMS 2785-2790, 2797-2803).

\section{Results and Discussion}

Two species of Timulla that parasitize Exomalopsis fulvofasciata nests were collected, as follows: 20 individuals of Timulla terminalis (Gerstaecker, 1958), and 6 individuals of Timulla intermissa Mickel, 1938, parasitizing E. fulvofasciata nests. Timulla intermissa has been recorded for the Cerrado and Atlantic Forest biomes (Mickel 1938, Aranda \& Catian 2008) and our study reports for the first time this species in Pantanal floodplain.

Exomalopsis Michener (Hymenoptera: Apidae, Anthophorinae) are solitary bees that nest in the soil, where individuals provide resources for the development of their larvae (Rozen Junior 1984, Norden et al. 1994). Here we observed that females of $E$. fulsvofasciata built their nests in open areas with sandy soil, in a high concentration of nests: $83 \%$ were complete and $17 \%$ under construction in five plots of $1 \mathrm{~m}^{2}$. Timulla females were observed in this area, entering and staying there for about five minutes in the complete nests and in those under construction.

Our study shows the first record of E. fulvofasciata as a potential host of Timulla species. Species of Timulla have already been recorded parasitizing other hymenopterans: Solenopsis invicta Buren, 1972 (Formicidae) (Brothers et al. 2000), Epicharis sp. (Apidae) (Rocha-Filho et al. 2008) and species of Sphecidae and Eumeninae (Vespidae) (Quintero \& Cambra 1996, Cambra \& Quintero 1993). Other species of Exomalopis have already been recorded as hosts of mutillids. Exomalopsis solani Cockerell, 1896, was parasitized by Pseudomethoca bethae Krombein, 1992 in Arizona and New Mexico, USA (Norden et al. 1994) and Horcomutilla sp. in Mato Grosso do Sul, Brazil (Lima et al. 2008).

The nests were monitored over six months, but due to Pantanal flood pulses, nest openings were destroyed and the emergence of hosts and parasitoids could not be monitored, and, thus, it has not been possible to obtain data on the frequency of parasitism for the species. The considerable number of Timulla seen upon entering bee nests over a short time interval indicates that the use of E. fulsvofasciata nests in the Pantanal region is not accidental. We consider the behavior of Timulla females in the nests of E. fulsvofasciata as an evidence of parasitism, however future research is also necessary to better understand the ecological relationships involving these species.

\section{References}

ARANDA, R. \& CATIAN, G. 2008. Novos registros de Mutillidae (Hymenoptera-Aculeata) para o Estado de Mato Grosso do Sul, Brasil. Rev. Biocien. 14(1):62-68.

BERGAMASCHI, A.C.B., CAMBRA, R. \& MELO, G.A.R. 2010. Male description and host record for Lophomutilla corupa Casal, 1968 (Hymenoptera: Mutillidae), with behavioural notes on mating behaviour and host nest attacks. Journ. Nat. Hist. 44(43):2597-2607. http://dx.doi. org/10.1080/00222933.2010.499574

BERGAMASCHI, A.C.B., CAMBRA, R. \& MELO, G.A.R. 2011. New combinations, sex association, behavioural notes and potential host record for two Neotropical species of Pseudomethoca Ashmead, 1896 (Hymenoptera: Mutillidae). Zootaxa. 3062:55-63.

BERGAMASCHI, A.C.B., CAMBRA, R., BROTHER, D.J. \& MELO, G.A.R. 2012. Lynchiatilla Casal, 1963 (Hymenoptera: Mutillidae):a new species from Brazil associated with Paroxystoglossa spiloptera Moure (Hymenoptera: Apidae: Halictinae), and notes on other species. Zootaxa. 3548:55-64.

BROTHERS, D.J. 2006. Família Mutillidae. In Introducíón a los Hymenoptera de la región Neotropical (F. Fernandes \& M.J. Sharkey, eds.). Sociedad Colombiana de Entomología, p.565-583.

BROTHERS, D.J., TSCHUCH, G. \& BURGER, F. 2000. Associations of mutillid wasps (Hymenoptera, Mutillidae) with eusocial insects. Insectes soc. 47:201-211. http://dx.doi.org/10.1007/PL00001704

CAMBRA, T.R.A. \& QUINTERO, A. 1993. Studies of Timulla Ashmead (Hymenoptera: Mutillidae):New distribution records and synonymies, and descriptions of previously unknown allotype. Pan-Pac. Entomol. 69:299-313.

CRESSON, E.T. 1902. Descriptions of some Mutilla from Brazil. Trans. Am. Entomol. Soc. 28:1-82.

CUNHA, R. 2004. Monoeca xanthopyga (Hymenoptera, Apoidea, Tapinotaspidini), primeiro registro de hospedeiro para parasitóide do gênero Traumatomutilla (Hymenoptera: Mutillidae) na Serra Geral do Rio Grande do Sul, Brasil. Acta Scien. 6(2):35-40. 
JUNK, W.J., BAYLEY, P.B. \& SPARKS, R.E. 1989. The flood pulse concept in river-floodplain systems. Aquat. Sci. 106:110-127.

MICKEL, C.E. 1938. The Neotropical mutillid wasps of the genus Timulla Ashmead (Hymenoptera: Mutillidae). Trans. R. Entomol. Soc. Lond. 87:529-680. http://dx.doi.org/10.1111/j.1365-2311.1938.tb00728.x

MICKEL, C.E. 1969. Pseudomethoca Willei N. Sp. Reared from Cells of the Bee Lasioglossum (Dialictus) umbripenne (Ellis) (Hymenoptera: Mutillidae; Apoidea). J. Kans. Entomol. Soc. 42(4):524-526.

NORDEN, B.B., KROMBEIN, K.V. \& BATRA, S.W.T. 1994. Nests and enemies of Exomalopsis (Phanamalopsis) solani Cockerell (Hymenoptera: Apoidea, Mutillidae; Diptera: Asilidae). Proc. Entomol. Soc. Wash. 96(2):350-356.

QUINTERO, D. \& CAMBRA, R.A. 1996. Timulla centroamericana (Dalla Torre) (Hymenoptera: Mutillidae), a parasitoid of Liris (Hymenoptera: Sphecidae). Southwest. Entomol. 21(2):205-207.
LIMA, F.V.O., SILVESTRE, R., ARANDA, R. \& BALESTIERI, J.B.P. 2008. Ocorrência de parasitismo em Exomalopsis aureopilosa Spinola, 1853 (Hymenoptera, Apidae) por Horcomutilla sp. Casal, 1962 (Hymenoptera, Mutillidae). In VIII Encontro sobre Abelhas - Biodiversidade e Uso Sustentável.

ROCHA-FILHO, L.C., SILVA, C.I., GAGLIOANONE, M.C. \& AUGUSTO, S.C. 2008. Nesting behavior and natural enemies of Epicharis (Epicharis) bicolor Smith 1854 (Hymenoptera: Apidae). Trop. Zool. 21:227-242.

ROZEN JUNIOR, J.G. 1984. Comparative nesting biology of the bee tribe Exomalopsini (Apoidea, Anthophoridae). Am. Mus. Novit. 2798:1-37.

WILSON, J.S. 2010. Historical Biogeography of Velvet Ants (Hymenoptera: Mutillidae) in the North American Deserts and Arid Lands. PhD Thesis, Utah State University, Utah.

YANEGA, D. 1994. Arboreal, Ant-Mimicking Mutillid Wasps, Pappognatha; Parasites of Neotropical Euglossa (Hymenoptera: Mutillidae and Apidae). Biotropica 26(4):465-468. http://dx.doi.org/10.2307/2389242 